\title{
Waste to Energy Potential of Domestic Waste Cooking Oil in Guayaquil: A review.
}

\author{
J. Hidalgo-Crespo, M. Sc. ${ }^{1,3}$, S. Coello-Pisco, Mg. ${ }^{1,3}$, T. Crespo-Vaca, Mg. ${ }^{1}$, J. L. Amaya, PhD. ${ }^{2}$, M. Soto, PhD. ${ }^{3}$, F. \\ X. Jervis, PhD. ${ }^{2}$ and C. M. Moreira, PhD. ${ }^{2}$ \\ ${ }^{1}$ Universidad de Guayaquil, Ecuador,jose.hidalgocr@ug.edu.ec, silvia.coellop@ug.edu.ec and tania.crespov@ug.edu.ec. \\ ${ }^{2}$ ESPOL Polytechnic University, Escuela Superior Politécnica del Litoral, ESPOL, Ecuador, jlamaya@espol.edu.ec, \\ fjervis@espol.edu.ec and cemoreir@espol.edu.ec. \\ 33niversidade da Coruña, Spain,j.hidalgo@udc.es, silvia.coellopisco.silvi@udc.es andm.soto@udc.es.
}

\begin{abstract}
This paper examines the opportunity for waste cooking oil as a potential source of energy by means of (i) production of biodiesel, (ii) direct burning and (iii) biodegradation. It offers a profound review of existing literature and it measures possible uses of the waste cooking oil produced in the city of Guayaquil. In addition, important chemical and physical properties are presented after the development of a sampling process for after laboratory testing. Conclusions show that the most suitable technology is biodiesel generation, followed by biodegradation, but direct burning is found to be not a possible solution due to its kinematic viscosity.
\end{abstract}

Keywords-DWCO, Waste-to-Energy, Characterization, Physical \& Chemical Properties.

\section{INTRODUCTION}

The constant increase in population combined with the search for comfort and our daily activities become factors which contribute to the growing generation of waste. Any residue or waste that may cause damage to health or the environment should be considered as dangerous; sufficient argument for sectional or central governments to take responsibility for promoting the adoption of measures to reduce the maximum generation of these wastes, as well as establishing policies and strategies for their management and disposal without damaging the environment and reducing their harmful properties through appropriate techniques [1].

Ecuador is vouching a peak in industrialization , urbanization and population, which is setting a surmounting pressure on the nation's resources and generating a sprouting amount of waste [2]. In this context, domestic waste (DW) is waste, which is either solid or liquid and, it's an unwanted and obviously an undesirable residue, generated in the residential areas of the city. In Guayaquil, total average solid domestic waste per capita accounts for $2.45 \mathrm{~kg}$ daily, from which $75 \%$ is organic (kitchen waste), followed by plastic with $8 \%$ and paper \& cardboard with $6 \%$. Biodegradable waste is $81.8 \%$ and nonbiodegradable waste comprise $18.2 \%$ by weight of total domestic waste per day per capita [3]. However, there is almost non-scientific research for liquid wastes in the city.

The increasing living level of the population has led to a much higher demand of edible oils given that they provide essential nutrients and energy for everyone's daily activities [4]. Edible oil is a fatty liquid that is physically extracted from several vegetables and some animal tissues, being the most

Digital Object Identifier (DOI):

http://dx.doi.org/10.18687/LACCEI2020.1.1.485

ISBN: 978-958-52071-4-1 ISSN: 2414-6390 common olive oil [5], and like most organic molecules, cooking oils are made of carbon $(\mathrm{C})$, hydrogen $(\mathrm{H})$ and oxygen $(\mathrm{O})$ which further unite to create triglyceride.

Additionally, million tons of edible cooking oil is consumed every year worldwide, out of which $20 \%$ is considered as waste [6]. During deep-frying, several chemical reactions occur, such as: hydrolysis, oxidation, thermal decomposition and polymerization. Also, it increases the polar materials and decreases the unsaturated fatty acids, becoming no longer good for human consumption [4] [7].

Every year, thousands of fatty liquid wastes are discarded into the local sewage system. Among kitchen generated wastes, waste cooking oil (WCO) and fat create serious problems for their disposal due to its slow degradation rate [8]. The term waste cooking oil refers to oil that has been used for food production at high temperatures and which is no longer viable for its intended use [9] [10]. Approximately 100 million of gallons of WCO was produced daily in USA in 2008, according to the energy information administration, and the average per capita WCO generation was of 9 pounds $(4,088$ grams) [11]. Previous work estimated the daily amount of WCO per capita for the city of Guayaquil to be of 5.11 grams meaning a projection of almost 5,036 tons of this waste for the city in the time lapse of one year [12]. Such enormous difference occurs because per capita generation of WCO in USA accounts for restaurants and other vegetable oil consuming businesses whilst for Ecuador only domestic.

When used cooking oils are discharged through the kitchen sink or toilets, with other types of waste, it usually forms a crust of dirt, clogging the internal facilities and sewage systems, reducing sewer diameter and in extreme cases completely blocking the pipes and causing flooding [13]. In addition, they become a potential source of contamination of rivers, lakes, and many different water vessels [14]. Then, huge investment needs to be done by the local authorities for the functioning of the wastewater treatment plants to ensure proper cleanliness of the flow that will reach the local rivers at the end, problems to the biological treatment phases can cause undesired stops for maintenance with a relative increase of the management costs [15]. González Iñigo [16], remarks that one liter of used cooking oil contains 5,000 times more pollutant load than the black waters that flow through the sewers and can contaminate up to 40,000 liters of water, which is the equivalent of a person's annual sanitary water consumption. Vidal-Benavides [17], indicates that one liter of

18th LACCEI International Multi-Conference for Engineering, Education, and Technology: "Engineering, Integration, and Alliances for a Sustainable Development" "Hemispheric Cooperation for Competitiveness and Prosperity on a Knowledge-Based Economy", July 27-31, 2020, Virtual Edition. 
used vegetable oil poured in a water vessel can contaminate approximately 50,000 liters of fresh water. Milano [18], estimates that one liter of oil mixed with one million liters of water is enough to make the taste change and finally turning it non-potable.

This environmental problem could be solved by proper utilization and management of the domestic waste cooking oil. The $7^{\text {th }}$ Environmental Action Programme of the European Commission defines circular economy as where nothing is wasted and where natural resources are managed sustainably, and biodiversity is protected [19]. A circular economy is restorative and regenerative by design and it is intended to always keep products, components and materials at their highest levels. It is a positive continuous development cycle that preserves and increases the natural capital, optimizes the yields of the resources and minimizes the risks of the system, managing the finite stocks and renewable flows [20] [21].

The optimization of resource usage would create a route towards attaining sustainability. The 3R's (Reduce, Reuse, Recycle) ought to be kept in mind while working the choice of technology to obtain sustainability in the final disposal of residues. In this context, waste cooking oil is among many materials that can be recycled such as: plastics, paper, cardboard, glass, aluminum, tires and wood.

Waste to Energy (WtE) is a waste treatment process that generates energy in the form of electricity and heat through incineration. It is considered a type of thermo-chemical conversion and energy recovery with an objective of avoiding that waste reaches landfill. It helps with reducing the amount of waste thrown away in the sewage system by keeping material cycles, and ultimately the environment and humans largely free from toxic substances [22]. Finally, waste-toenergy allows recovery of both energy and materials from non-recyclable waste and hence contributes to keeping materials in circulation.

However, in order to be able to measure the potential of WCO for energy, as a first necessary step there's the need to characterize this liquid waste. Then, the aim of this paper is to present the domestic cooking waste oil characterization and determine its potential for energy generation with the help of information extracted from different research.

For this purpose, first the state-of-the-art information on waste cooking oil reuse is presented in section 2. After, the developed methodology for obtaining a sample for testing in laboratory is introduced in section 3. Later, the physical and chemical laboratory results are shown in section 4. Following, discussion on the best available waste-to-energy technology occurs in section 5. Finally, principal conclusions are given in section 6 .

\section{LITERATURE REVIEW}

Waste cooking oil is considered a low-cost and renewable feedstock to produce energy and biobased products if it can be financially and professionally collected and recycled [4]. The recycling of this waste is gaining increasing attention as society begins to be aware of the environmental, economic and social benefits of this activity. However, some factors could affect its recovery as the lack of a supervision entity, a demand market that gives a value to the waste or perhaps incentives to the household owners to separate in bins their liquid oil and fatty waste.

Waste cooking oils represent a renewable resource that can be used as reliable raw material to access new products to a wide array of structural and functional variations. Its availability and much lower cost make it an industrially attractive for various industries. Also, it should be remarked that due to their chemical-physical characteristics, pure vegetable oil and waste vegetable oil behave similarly [15]. However, accurate data of physical and chemical characterization of domestic waste cooking oil for the city is necessary in order to make correct calculations and give the best possible solutions.

\subsection{Physical and Chemical Characteristics}

A drawback of the use of residual cooking oils as raw material for direct or indirect energy generation is that they have different properties than those of refined or raw oils, since they are degraded by hydrolytic and oxidative reactions that occur during use. Many authors mention the most important physical and chemical characteristics to be tested for waste cooking oil: Protein Content (PC), Lipids Content (LC), Moisture (M), Ashes (As), Free Fatty Acids (FFA), Iodine Index (II), Saponification Index (SI), Volatile Matter (VM), Total Solids (TS), Kinematic Viscosity (CV), Density (D), PH, Peroxides Index (PI), Refraction Index (RI) and Specific Weight (SW) [15] [23] [24] [25] [26] [27].

\subsection{Bioenergy Potential}

Energy is an essential constituent of human life that enables humanity to function and deliver their daily activities. It's a vital element which achieves socioeconomic development on a global level. Given the increasing urbanization and modernization, there is an intense growth in the fossil fuel demand. However, the world offer will continue decreasing being a non-self-recuperated resource. An alternative eco-friendly and economically available fuel is required to keep the lights on. Three different paths appear: (i) the conversion of WCO to biodiesel, (ii) direct combustion in an engine, and (iii) production of biogas with a process of biodegradation. All three options can contribute to a reduction of greenhouse gas emissions [28].

\subsubsection{Biodiesel}

The depletion of easily accessible fossil fuels is currently one of the most troubling topics, since they are finite sources. For this reason, biomass derived biofuels have emerged to be a priceless source mainly for third-world countries such as 
Ecuador and could help to cut down the petroleum imports. Reusing waste cooking oil as raw material for biodiesel production can diminish environmental pollution (when compared to directly thrown into the environment) and improve urban air quality due to its renewable character and very low sulfur content [4].

The development of a method to obtain biodiesel can reduce the dependence over petroleum based liquid fuels. Also, converting waste cooking oil into biofuel represents a three-win solution, dealing with food security, contamination and energy assurance [29] [30].

Biodiesel is normally produced by transesterification of fatty acids in waste vegetable oils, using an alkaline catalyst (sodium or potassium hydroxide) [31]. In the biodiesel production industry, the yield is defined as weight of biodiesel/weight of feedstock, and of course the value can never surpass $100 \%$ because of the loss during the production process. Among the research, data produce an average yield value of $96.55 \%$ with minimum and maximum values between 93.80\% and 99.33\% [1] [7] [17] [26] [32] [33].

One application for biodiesel is burning in the internal combustion engine. Results reveal that based on performance viewpoint, different blends of diesel and waste cooking oil biodiesel could show much better exhaust gases profiles [34], such as: low emissions of sulfur oxides (SOx), carbon monoxide (CO), particulate matter and unburned hydrocarbons [35], and higher power and torque output and lesser fuel consumption [36]. Brahma et al. [37], developed an investigation to analyze the combustion characteristics and thermal efficiency of a diesel engine finding that the best combustion characteristics and energy conversion efficiency occur at a $20 \%$ blend.

However, before using the WCO for biodiesel production, pretreatment is necessary, to match the oil residue properties, to those income needed characteristics of the transesterification process. After comes neutralization, washing and distillation to improve the fuel chemical-physical characteristics, especially to decrease viscosity [38].

\subsubsection{Direct Combustion}

A different approach is reusing the WCO as an energy source for direct burning in boilers, heaters, combustion engines, incinerators or cooking stove, due to its high calorific potential (around HHV of $41 \mathrm{MJ} / \mathrm{kg}$ [39] and LHV of 37 $\mathrm{MJ} / \mathrm{kg}$ [40]). The utilization of this waste in burners represents an attractive alternative to the use of heating fuel oil in heat production for domestic heating, small industrial units, drying of various products, among others [41].

Vegetable oils are bioliquids since they are liquid fuels obtained from agricultural products, animal fats and marine plants. The use of vegetable oils as a fuel in stoves or burners is an alternative which offers many advantages over its use in internal combustion engines [42]. Natarajan et al. [43] found the efficiency of waste vegetable oil used as fuel for a cooking stove to be as high as $48.9 \%$ compared to that of the conventional stove which is $34.9 \%$. Oprea et al. [44], during their experiment in a pilot burner demonstrated the possibility to generate energy in similar condition with LFO or diesel fuel, without major modification of the actual installations.

Rudolph Diesel, in his patent he wrote that the "use of vegetable oil for engine fuel may seem insignificant today but such oil may become in the cause of time, as important as petroleum" [45]. In general, the use of WCO in diesel engines is much more feasible for stationary production of electrical or thermal energy, rather than for automotive applications. WCO has enough potential to run a compression ignition engine. However, its density is about ten times higher than that of mineral diesel [46] creating some extra costs for maintenance. But, by cleaning, preheating and blending, waste cooking oil will give a better performance, although a too high preheated oil may interfere with the injection system [47].

\subsubsection{Biodegradation}

Every year, enormous quantities of waste cooking oil is produced worldwide. Currently they are reused mainly for biodiesel production. Biodiesel generation means an environmental problem, because of the pretreatment to eliminate moisture and bulky particles and then through a refining process to eliminate free fatty acids and undesirable compounds [48].

Lipids inside WCO have a very high potential for biogas bio-methanation during anaerobic digestion [49]. Normally WCO is used as co-substrate of other lipid fat waste to enhance anaerobic digestion and yield bigger values of methane. This is due to the long chain fatty acids (LCFA), which have a toxic effect on microbial life.

The anaerobic co-digestion offers great potential for the proper disposal of the organic fraction of solid domestic waste and it can be defined as the simultaneous treatment of two or more organic biodegradable waste streams by anaerobic digestion [50]. For instance, Da Silva et al. [51], combined swine manure with waste cooking oil in a proportion of 45.6 to 66.7 waste cooking oil $/ \mathrm{kg}$ manure, obtaining better values than just swine manure. Sandriaty et al. [52], determined the effect of WCO into co-digestion process of food waste to produce biogas, being the result a methane yield of $485 \mathrm{~mL}$ $\mathrm{CH} 4 /$ gr Volatile Solids.

\subsection{Other recycling possibilities}

Waste cooking oil, due to their unique properties of availability and biodegradability can be considered as a reliable substitute for petroleum-based oils in transformer's cooling system [53]. Also, discarded oil can be used in the manufacturing of toilet soap [54] and as an anti-aging agent for both short- and long-term bitumen production [55].

\section{METHODOLOGY}


Considering that there are no previous studies for domestic waste cooking oil characterization for the city of Guayaquil, this is the first attempt for determining the most important physical and chemical characteristics of this waste. In previous research, we measured the quantity of DWCO produced in the city and a total of five tanks of 20 liter each were filled with the 2-week cooking oil waste from 441 households [12]. These tanks rested indoors for a period of two months, allowing water and heavy waste to decant and light grease to float. Meaning that first, homogenization of the waste cooking oil must be done. After, to obtain a valid sample for testing, a research project was elaborated for students of a local university of the city, for the period of three months from November 2019 to January 2020. They were asked to i) research for the most necessary characteristics that need to be tested according to the literature, ii) elaborate a procedure to obtain a valid sample of WCO from the plastic tanks and iii) look for certified laboratories for testing the characteristics previously selected according to the research, and finally iv) obtain and send a sample for testing. An important remark to mention is that the laboratories ask for a minimum volume of sample, depending of the number of tests needed. This had to be taken also in consideration for the sample obtaining procedure.

As mention in the previous section, the principal characteristics to be measured are: Protein Content (PC), Lipids Content (LC), Moisture (M), Ashes (As), Free Fatty Acids (FFA), Iodine Index (II), Saponification Index (SI), Volatile Matter (VM), Total Solids (TS), kinematic Viscosity (KV), Density (D), PH, Peroxides Index (PI), Refraction Index (RI) and Specific Weight (SW).

There was no single laboratory that could run all the tests required so, two certified laboratories were chosen in order to do all the tests. Each laboratory required a total of 1.5 liters, then a total of 3 liters needed to be extracted from the almost 100 liters available from the five tanks. To develop the procedure, two international standards were accessed:

- ISO 5555:2001: Animal and vegetable fats and oils - Sampling.

- ISO 11648.2003: Statistical aspects of sampling from bulk materials.

Finally, the sampling procedure remained as follows: First, homogenization of the WCO in the tank by stirring with one round stainless-steel bar for 30 seconds and shaking the tank up and down for 15 seconds. This procedure needed to be repeated 5 times. After, pouring the content into a different plastic vessel, taking different 100 milliliter samples while doing it. One at the beginning, another when half of oil have been poured and one at the end. This meant a total of 300 milliliters. This procedure had to be done twice per tank to obtain the 3 liters needed.

Materials used for the procedure were: i) one round stainless steel bar of $1 / 4$ inch and $50 \mathrm{~cm}$ long, ii) one large plastic tank of at with a volume of at least 20 liters, iii) pair of gloves, iv) one funnel, v) one glass with measurement in $\mathrm{ml}$ of at least $500 \mathrm{ml}$ and vi) 3.0 liters sample collection vessel.

\section{RESULTS}

Table 1 shows the laboratory results for the waste cooking oil samples sent to laboratory number 1. Environmental conditions during the testing were $20^{\circ} \mathrm{C}$ and $40 \%$ of relative humidity.

TABLE I

WASTE COOKING OIL CHARACTERIZATION - 1

\begin{tabular}{|c|c|c|}
\hline Parameter & Result & Unit \\
\hline Moisture & 0.38 & $\%$ \\
\hline Peroxides Index & No detectable & - \\
\hline Refraction Index & 1.446 & - \\
\hline Volatile Matter & $0.08 \%$ & $\%$ \\
\hline pH & 5.335 & - \\
\hline kinematic Viscosity & 68.5 & $\mathrm{cSt}$ \\
\hline Density & 0.8958 & $\mathrm{~g} / \mathrm{mL}$ \\
\hline Specific Weight & 8,866 & $\mathrm{~N} / \mathrm{m}^{3}$ \\
\hline
\end{tabular}

Table 2 shows the laboratory results for the waste cooking oil samples sent to laboratory number 2. Environmental conditions during the testing were $24.3^{\circ} \mathrm{C}$ and $48 \%$ of relative humidity.

TABLE II WASTE COOKING OIL CHARACTERIZATION - 2

\begin{tabular}{|c|c|c|}
\hline Parameter & Result & Unit \\
\hline Protein Content & No detectable & - \\
\hline Lipids Content & 99.19 & $\%$ \\
\hline Ashes & No detectable & - \\
\hline Free Fatty Acids & 2.98 & $\%$ \\
\hline Iodine Index & 34.84 & $\%$ \\
\hline Saponification Index & 161.995 & $\mathrm{mgKOH} / \mathrm{g}$ \\
\hline Volatile Matter & 0.38 & $\%$ \\
\hline Total Solids & 0.58 & $\%$ \\
\hline
\end{tabular}

The determination of the percentage of free fatty acids (FFA) is an important parameter when defining whether it is necessary or not to carry out the process of obtaining biodiesel in two stages: esterification and transesterification. In general, esterification is carried out under acidic conditions, while transesterification is carried out under alkaline conditions. The criterion for performing the reaction in two stages is the percentage of free fatty acids, which must be greater than $1 \%$ [26]. Given that the value of FFA from the sample is $2.98 \%$, then it is necessary to obtain biodiesel in the two stages.

Density and even more so viscosity play an important role in the evaluation of fuel performance. To ensure good combustion efficiency, values of density should be below $0.860 \mathrm{~g} / \mathrm{mL}$, corresponding to the inferior density limit given by the EN 14214:2008 European standard [56] for biodiesel fuel in diesel engines. The kinematic viscosity plays also a key factor to consider in order to achieve optimal fuel atomization. Values should remain under $6 \mathrm{cSt}$ [57]. Results values for WCO showed a density of $0.8958 \mathrm{~g} / \mathrm{mL}$ and a kinematic viscosity of $68.5 \mathrm{cSt}$. Density is close to the standard; however 
kinematic viscosity is almost 12 times passed the maximum limit. Then, if the WCO is intended for direct burning, a pretreatment must occur.

Iodine Index measures the unsaturated fatty acids (USFA) by determining the amount of iodine (grams) that can be incorporated into $100 \mathrm{~g}$ of biodiesel. The required limit is $120 \mathrm{~g} \mathrm{I}_{2} / 100 \mathrm{~g}$, according to standard EN 14214 [58]. Saponification value is expressed by potassium hydroxide in $\mathrm{mg}$ required to saponify one (1) gram of fat. It depends on the kind of fatty acid contained in the fat.

Moisture and total solids should be removed from the WCO if used for biodiesel production or direct combustion, however for biodegradation it's not necessary. Then, the first two processes wold leave some residues behind that the third wouldn't. This is an advantage of biodegradation.

Value of $\mathrm{pH}$ is slightly acid (5.335), and lipids content is very high. High content of lipids in food waste is good for biodiesel production but, could restrict digestion rate and give rise to the accumulation of long chain fatty acids in anaerobic digestion [59].

\section{DISCUSSION}

The growing energy needs in developing and emerging countries, give more importance to bio generated fuels. The use of waste cooking oil as a feedstock for these biofuels could effectively reduce costs and environmental impacts. Several end-uses for this waste appear attractive such as anaerobic digestion, combustion and more recently the production of biodiesel. Using $\mathrm{WCO}$ as fuel for energy production promotes waste recovery and valorisation in an intelligent manner, evading specific treatments in the wastewater plants. It's easy to collect from industries, households and restaurants, and it's much cheaper than refine oils.

The European Union defines biodiesel as a methyl ester produced from a vegetable or animal oil of similar quality to diesel oil for use as a biofuel [60]. Biodiesel from WCO is economically and technically viable. Its yield has been found as high as $99 \%$ and a potential low heating power of $37 \mathrm{MJ} / \mathrm{kg}$. Potential production of biodiesel for the city using DWCO is of 4,985 tones per year. Ecuador burns appproximately $3,092.5 \mathrm{TJ}$ of petroleum diesel each year $(1$ gallon of diesel $=$ $14,559.77 \mathrm{~kJ})$. Total available annual energy of biodiesel from domestic cooking waste could be as high as $184.455 \mathrm{TJ}$, which represents $5.96 \%$ of the demand. Using waste potential energy, would mean a diminish of approximately 13 million gallons of diesel every year.

Some drawbacks of this biofuel include higher emissions of NOx, less power output due to its higher oxygen content and greater thickness when compared to regular diesel fuel. Additionally, its storage can be affected due to its low oxidative stability, making it hard to develop the necessary production stock.

On the other hand, biodiesel production requires many preparation steps before it can pass to the transesterification process and produces some residues. This can be avoided if the waste cooking oil is used for direct combustion in chambers or internal combustion engines. Being abundantly present in almost all countries, it can be used for combined heat and power generation, but moisture and total solids need to be segregated first. Also, results show that viscosity of our WCO is almost 12 times higher than the standard, making it not suitable for direct burning and it's impossible to assure now just from research and without any experimentation that this value can be reduced by preheating and cleansing.

Finally, given the high lipids content of the WCO and its slight acidity, thinking of using this waste alone in a process of biodegradation to produce methane becomes not possible, due to the toxic effect this produces over the microorganisms. Studies suggest that co-generation between waste cooking oil and other sources of carbon, such as vegetables, kitchen waste or manure will give a bigger production of methane gas other than having one substrate.

\section{CONCLUSION}

The physical and chemical characterization of waste cooking oil for the city of Guayaquil was effectuated. For this purpose, a procedure to obtain a sample from a rigid tank was developed.

Biodiesel, direct combustion and biodegradation were found to be the most used techniques to recycle this waste in a context of waste-to-energy and an overview of each technique was given to evaluate replicability potential in Ecuador.

To our criterion, the best suited technology is the production of biodiesel, followed by biodegradation, although experimentation at pilot scale should occur first. Direct burning is not recommended due to the high kinematic viscosity of the domestic waste cooking oil.

\section{ACKNOWLEDGMENT}

The preferred spelling of the word "acknowledgment" in America is without an "e" after the "g." Try to avoid the stilted expression, "One of us (R. B. G.) thanks ..." Instead, try "R.B.G. thanks ..." Put sponsor acknowledgments in the unnumbered footnote on the first page.

\section{REFERENCES}

[1] Sahafi, S. M., Goli, S. A. H., Tabatabaei, M., Nikbakht, A. M., \& Pourvosoghi, N. (2016). The reuse of waste cooking oil and spent bleaching earth to produce biodiesel. Energy Sources, Part A: Recovery, Utilization and Environmental Effects, 38(7), 942-950. doi:10.1080/15567036.2013.860505.

[2] Kalyani, K. A., \& Pandey, K. K. (2014). Waste to energy status in India: A short review. Renewable and Sustainable Energy Reviews, 31, 113120. doi:10.1016/j.rser.2013.11.020.

[3] Hidalgo-Crespo, J., Amaya, J., Jervis, F., Moreira, C., Crespo-Vaca, T., Zabala-Ortiz, G., \& Coello-Pisco, S. (2019). Waste-to-energy incineration: Evaluation of energy potential for urban domestic waste in Guayaquil. RISTI - Revista Iberica De Sistemas e Tecnologias De Informacao, 2019(E23), 392-403.

[4] Tsai, W.-T. (2019). Mandatory Recycling of Waste Cooking Oil from Residential and Commercial Sectors in Taiwan. Resources, 8(1), 38. doi:10.3390/resources 8010038 
[5] Da-Wen Sun. (2018). Modern Techniques for Food Authentication, Second Edition.

[6] Avinash, A., \& Murugesan, A. (2018). Prediction capabilities of mathematical models in producing a renewable fuel from waste cooking oil for sustainable energy and clean environment. Fuel, 216, 322-329. doi:10.1016/j.fuel.2017.12.029.

[7] Sodhi, A. K., Tripathi, S., \& Kundu, K. (2017). Biodiesel production using waste cooking oil: a waste to energy conversion strategy. Clean Technologies and Environmental Policy, 19(6), 1799-1807. doi:10.1007/s10098-017-1357-6.

[8] D. C. Panadare, V. K. Rathod (2015). Applications of Waste Cooking Oil Other Than Biodiesel: A Review. Iranian Journal of Chemical Engineering, Vol. 12, No. 3.

[9] Adebayo, J. O., Napiah, M., Ibrahim, K., \& Raduan Kabit, M. (2018). Evaluation of Waste Cooking Oil as Sustainable Binder for Building Blocks. E3S Web of Conferences, 65, 05003. doi:10.1051/e3sconf/20186505003.

[10] Zhang, H., Wang, Q., \& Mortimer, S. R. (2012). Waste cooking oil as an energy resource: Review of Chinese policies. Renewable and Sustainable Energy Reviews, 16(7), 5225-5231. doi: 10.1016/j.rser.2012.05.008.

[11] Chhetri, A., Watts, K., \& Islam, M. (2008). Waste Cooking Oil as an Alternate Feedstock for Biodiesel Production. Energies, 1(1), 3-18. doi:10.3390/en1010003.

[12] Hidalgo-Crespo, J., Coello-Pisco, S., Crespo-Vaca, T., Borja-Caicedo, D. \& Lopez-Vargas, A. (2020). Domestic waste cooking oil (DWCO) generation in the city of Guayaquil and its relationship with social indicators. Paper presented for revision at the 18th LACCEI International Multi-Conference for Engineering, Education, and Technology.

[13] Ortner, M. E., Müller, W., Schneider, I., \& Bockreis, A. (2016). Environmental assessment of three different utilization paths of waste cooking oil from households. Resources, Conservation and Recycling, 106, 59-67. doi:10.1016/j.resconrec.2015.11.007

[14] R. B. de Oliveira, M. S. Ruiz, M. L. Gabriel Dias da Silva, A. Struffaldi and E. Bocatto, "Environmental sustainability and reverse logistics: An analysis of the recycling networks of cooking oil waste in Sao Paulo, Brazil," Proceedings of PICMET '14 Conference: Portland International Center for Management of Engineering and Technology; Infrastructure and Service Integration, Kanazawa, 2014, pp. 2756-2763.

[15] Capuano, D., Costa, M., Di Fraia, S., Massarotti, N., \& Vanoli, L. (2017). Direct use of waste vegetable oil in internal combustion engines. Renewable and Sustainable Energy Reviews, 69, 759-770. doi:10.1016/j.rser.2016.11.016

[16] González Canal, Iñigo \& González Ubierna, José Antonio. (2015). Problemática ambiental, incidencias en redes de saneamiento y coste del tratamiento en depuradoras de los aceites usados en cocina. Retrieved from: https://www.aguasresiduales.info/revista/articulos/problematicaambiental-incidencias-en-redes-de-saneamiento-y-coste-del-tratamientoen-depuradoras-de-los-aceites-usados-en-cocina.

[17] Vidal-Benavides, A. I., Quintero Díaz, J. C., \& Herrera-Orozco, I. (2017). Análisis de ciclo de vida de la producción de biodiesel a partir de aceite vegetal usado. DYNA, 84(201), 155. doi:10.15446/dyna.v84n201.54469.

[18] ] Milano SR. La produzione di biodiesel da olio vegetale esausto, presented at BioDieNet. Italy: Milan; 2008

[19] Olabi, A. G. (2019). Circular Economy and Renewable Energy. Energy. doi:10.1016/j.energy.2019.05.196.

[20] Emilio Cerdá \& Aygun Khalilova. (2016). Economía Circular. Economía industrial No. 401, 11-20.

[21] Prieto Sandoval, V., Jaca, C. and Ormazabal, M., Circular Economy: Relationship with the Evolution of the Concept of Sustainability and Strategies for its Implementation (in Spanish), Engineering Research Report, Vol. 15, pp 85-95, 2017.

[22] Van Caneghem, J., Van Acker, K., De Greef, J. et al. Waste-to-energy is compatible and complementary with recycling in the circular economy. Clean Techn Environ Policy 21, 925-939 (2019). https://doi.org/10.1007/s10098-019-01686-0.

[23] Tacias Pascacio, Veymar Guadalupe, Rosales Quintero, Arnulfo, \& Torrestiana Sánchez, Beatriz. (2016). Evaluación y caracterización de grasas y aceites residuales de cocina para la producción de biodiésel: un caso de estudio. Revista internacional de contaminación ambiental, 32(3), 303-313. https://dx.doi.org/10.20937/RICA.2016.32.03.05

[24] MURCIA ORDOÑEZ, Betselene et al. Caracterización de biodiesel obtenido de aceite residual de cocina. Revista Colombiana de Biotecnología, [S.1.], v. 15, n. 1, p. 61-70, ene. 2013. ISSN 1909-8758.

[25] Juárez-Morán, Luis Alberto, \& Ariza-Ortega, José Alberto, \& RamosCassellis, María Elena, \& Luna-Suárez, Silvia, \& Díaz-Reyes, Joel (2016). ANÁLISIS DE LA PRODUCCIÓN DE BIODIESEL POR TRANSESTERIFICACIÓN A PARTIR DE ACEITES CRUDOS DE PULPAS DE AGUACATE (Persea americana MILL VAR. HASS, FUERTE Y CRIOLLO) DE CLASE III. Interciencia, 41(11),774-780.

[26] Bocanegra, J. P., Malagón, D. H., \& López, L. F. (2015). Obtención de biodiesel a partir de aceite usado de cocina por transesterificación. Ingeniería y Universidad, 19(1), 155. doi:10.11144/javeriana.iyu191.odba.

[27] Wesolowski, M. (1987). Quality Assessment of Edible Fish Oils by Thermal Analysis Techniques. Fett Wissenschaft Technologie/Fat Science Technology, 89(3), 111-116. doi:10.1002/lipi.19870890306.

[28] Spencer, S., Scott, M., \& Macken, N. (2018). A Life Cycle Assessment of Biofuel Produced From Waste Cooking Oil. Volume 6A: Energy. doi:10.1115/imece2018-86301.

[29] Dorado, M. P., Cruz, F., Palomar, J. M., \& López, F. J. (2006). An approach to the economics of two vegetable oil-based biofuels in Spain. Renewable Energy, 31(8), 1231-1237.doi:10.1016/j.renene.2005.06. 010.

[30] Kathirvel, S., Layek, A., \& Muthuraman, S. (2016). Exploration of waste cooking oil methyl esters (WCOME) as fuel in compression ignition engines: A critical review. Engineering Science and Technology, an International Journal, 19(2), 1018-1026. doi:10.1016/j.jestch.2016.01.007.

[31] Stamenković, O. S., Veličković, A. V., \& Veljković, V. B. (2011). The production of biodiesel from vegetable oils by ethanolysis: Current state and perspectives. Fuel, 90(11), 3141-3155. doi:10.1016/j.fuel.2011.06. 049.

[32] BAUTISTA-VARGAS, M. E., PÉREZ-BRAVO, S., GARCÍANAVARRO, J. y HERNÁNDEZ-SÁNCHEZ, A. (2017). Biogeneración de energía sustentable utilizando residuos de aceite usado de cocina. Revista de Tecnología e Innovación. Septiembre 2017 Vol.4 No.12, 916.

[33] Sahar, Sadaf, S., Iqbal, J., Ullah, I., Bhatti, H. N., Nouren, S., ... Iqbal. (2018). Biodiesel production from waste cooking oil: An efficient technique to convert waste into biodiesel. Sustainable Cities and Society, 41, 220-226. doi:10.1016/j.scs.2018.05.037.

[34] Agrawal, B. N., Sinha, S., Kuzmin, A. V., \& Pinchuk, V. A. (2019). Effect of Vegetable Oil Share on Combustion Characteristics and Thermal Efficiency of Diesel Engine Fueled with Different Blends. Thermal Science and Engineering Progress, 100404. doi:10.1016/j.tsep.2019.100404.

[35] Mohammadshirazi, A., Akram, A., Rafiee, S., \& Bagheri Kalhor, E. (2014). Energy and cost analyses of biodiesel production from waste cooking oil. Renewable and Sustainable Energy Reviews, 33, 44-49. doi:10.1016/j.rser.2014.01.067.

[36] NÚÑEZ ISAZA, MANUEL LAUREANO; PRADA VILLAMIZAR, LAURA PATRICIA. DESEMPEÑO DE BIOCOMBUSTIBLES EN MOTORES DIESEL. Energética, [S.1.], n. 38, jul. 2007.

[37] Agrawal, B. N., Sinha, S., Kuzmin, A. V., \& Pinchuk, V. A. (2019). Effect of Vegetable Oil Share on Combustion Characteristics and Thermal Efficiency of Diesel Engine Fueled with Different Blends. Thermal Science and Engineering Progress, 100404. doi:10.1016/j.tsep.2019.100404

[38] César, A. da S., Werderits, D. E., de Oliveira Saraiva, G. L., \& Guabiroba, R. C. da S. (2017). The potential of waste cooking oil as supply for the Brazilian biodiesel chain. Renewable and Sustainable Energy Reviews, 72, 246-253. doi:10.1016/j.rser.2016.11.240.

[39] Ávila Calderón, C. A. (2016). Artículo Científico - Reciclaje de aceite vegetal de frituras para uso como biocombustible en motores diesel en diferentes proporciones. Universidad de las Fuerzas Armadas ESPE Extensión Latacunga. Carrera de Ingeniería Automotriz. 
[40] San José, J., Arroyo, Y., \& Sanz-Tejedor, M. A. (2019). Descriptive Statistical Analysis of Vegetable Oil Combustion in a Commercial Burner to Establish Optimal Operating Conditions. Energies, 12(12), 2372. doi:10.3390/en12122372

[41] Daho, T., Vaitilingom, G., Sanogo, O., Ouiminga, S. K., Zongo, A. S., Piriou, B., \& Koulidiati, J. (2014). Combustion of vegetable oils under optimized conditions of atomization and granulometry in a modified fuel oil burner. Fuel, 118, 329-334. doi:10.1016/j.fuel.2013.11.009.

[42] San José, J., Sanz-Tejedor, M. A., \& Arroyo, Y. (2015). Effect of fatty acid composition in vegetable oils on combustion processes in an emulsion burner. Fuel Processing Technology, 130, 20-30. doi:10.1016/j.fuproc.2014.09.036.

[43] Natarajan, R., Karthikeyan, N. S., Agarwaal, A., \& Sathiyanarayanan, K. (2008). Use of vegetable oil as fuel to improve the efficiency of cooking stove. Renewable Energy, 33(11), 2423-2427. doi:10.1016/j.renene.2008.01.022.

[44] I. Oprea, L. Mihăescu, T. Prisecaru, G.P. Negreanu, Experimental results of crude Vegetable Oil Burning for Energy generation, Proceedings of the 6th IASME/WSEAS International Conferance on heat transfer, Thermal engineering and environment HTE08, Rhodes, Greece, August 2008, ISSN: 1790-5095. ISBN: 978-960-6766-97-8, pp.391-395

[45] Vasudevan P, Sharma S, Kumar A. Liquid fuel from biomass: an overview: J Sci Ind Res 2005; 64 (11): 822.

[46] Gashaw, A., Teshita, A. 2014. Production of biodiesel from waste cooking oil and factors affecting its formation: A review. Int. J. Renew. Sustain. Energy. 3(5): 92-98, doi: 10.11648/j.ijrse.20140305.12.

[47] Dabi, M., \& Saha, U. K. (2019). Application Potential of Vegetable Oils as Alternative to Diesel Fuels in Compression Ignition Engines: A Review. Journal of the Energy Institute. doi:10.1016/j.joei.2019.01.003.

[48] Hidalgo, D., Gómez, M., Martín-Marroquín, J. M., Aguado, A., \& Sastre, E. (2014). Two-phase anaerobic co-digestion of used vegetable oils' wastes and pig manure. International Journal of Environmental Science and Technology, 12(5), 17

[49] Marchetti, R., Vasmara, C., Bertin, L., \& Fiume, F. (2020). Conversion of waste cooking oil into biogas: perspectives and limits. Applied Microbiology and Biotechnology. doi:10.1007/s00253-020-10431-3.

[50] Thanikal J.V., Rizwan S.M., Torrijos M., Yazidi H., Sousbie P., 2015.Anaerobic Co-Digestion of Vegetable Waste and Cooked Oil in an Anaerobic Sequencing Batch Reactor (ASBR).International Conference on Chemical Environmental and Biological Sciences (CEBS-2015), Dubai, UAE.

[51] Sunada, Natália da Silva, Orrico, Ana Carolina Amorim, Orrico Junior, Marco Antonio Previdelli, Lucas Junior, Jorge de, Lopes, Walter Renato Teixeira, \& Schwingel, Alice Watte. (2018). Anaerobic co-digestion of animal manure at different waste cooking oil concentrations. Ciência Rural, 48(7), e20170517. Epub July 23, 2018.https://doi.org/10.1590/ 0103-8478cr20170517.

[52] Reigina Sandriaty, Cindy Priadi, Septiana Kurnianingsih and Ayik Abdillah (2018). Potential of biogas production from anaerobic codigestion of fat, oil and grease waste and food waste. E3S Web Conf., 67 (2018) 02047 DOI: https://doi.org/10.1051/e3sconf/20186702047

[53] Bajestan, E., \& Werle, P. (2019). Feasibility Study of Waste Vegetable Oil as an Alternative Cooling Medium in Transformers. Applied Thermal Engineering. doi:10.1016/j.applthermaleng.2019.02.010.

[54] Girgis, A.Y. (2004). The utilization of discarded oil from potato chip factories in toilet soap making.

[55] Zhang, D., Chen, M., Wu, S., Liu, J., \& Amirkhanian, S. (2017). Analysis of the Relationships between Waste Cooking Oil Qualities and Rejuvenated Asphalt Properties. Materials (Basel, Switzerland), 10(5), 508. https://doi.org/10.3390/ma10050508.

[56] CEN. EN 14214:2008. Automotive fuels - Fatty acid methyl esters (FAME) for diesel engines - Requirements and test methods. Brussels: European Committee for Standardization(CEN); 2010.

[57] Selim MYE. Reducing the viscosity of Jojoba Methyl Ester diesel fuel and effects on diesel engine performance and roughness. Energy Convers Manage 2009;50:1781e8.

[58] L. Gouveia, ... I. Tzovenis, in Microalgae-Based Biofuels and Bioproducts, 2017.
[59] He J, Wang X, Yin XB, Li Q, Li X, Zhang Y F, et al. Insights into biomethane production and microbial community succession during semi-continuous anaerobic digestion of waste cooking oil under different organic loading rates. AMB Express. 2018; 8: 92. https://doi.org/10.1186/s13568-018-0623-2 PMID:29858702.

[60] Ian Homer y Evelyn Hunter (2007). Biodiesel, métodos artesanales para su fabricación. Facultad de Ciencias Agronómicas, Universidad de Chile. 